\title{
ANALISIS TINDAKAN WARGA DESA PAYAMAN DALAM MENCEGAH PENYAKIT DBD
}

\author{
ACTION ANALYSIS OF VILLAGERS PAYAMAN IN \\ PREVENTING DENGUE DISEASE
}

\author{
Didi Intan Pratiwi ${ }^{1)}$, Rachmat Hargono ${ }^{2)}$ \\ ${ }^{1}$ Departemen Administrasi Kebijakan Kesehatan, \\ Fakultas Kesehatan Masyarakat, Universitas Airlangga, Surabaya. \\ ${ }^{2}$ Departemen Promosi Kesehatan dan Ilmu Perilaku, \\ Fakultas Kesehatan Masyarakat, Universitas Airlangga, Surabaya. \\ Email: Didiintan.di@gmail.com
}

\begin{abstract}
Dengue Hemorrhagic Fever (DHF) is caused by dengue virus carried by Aides Aigepty mosquitoes. Since 2015 there has been a typical DHF in Payaman Village as 3 people and one of them was died in 2016. One typical of DHF has been an Extraordinary Occurrence in the health sector. One that can trigger dengue disease is the low rate of larvae free. Eradication of DHF can be done with Mosquito Nest eradication activity. In this study aims to analyze the actions of villagers who can trigger dengue disease and actions that can prevent dengue disease. The research method used is descriptive quantitative. Data source used is primary data and secondary data. Primary data was collected by interviewing questionnaires in each house. To support the completeness of the data used qualitative methods by conducting in-depth interviews on various related sectors. Secondary data is taken from Payaman Village Dasawisma data and Village Profile data. The results of the study found that the villagers of Payaman, especially RT 15-22 have acts that can trigger dengue fever, such as the handling of late dengue cases, not drain the water reservoir, poor waste management of households, the management of used less precise and laying the animal cage inside the house. While the actions that can be used to prevent dengue fever is using mosquito nets when sleeping and keep fish in water reservoirs. It needs to be improved by changing actions that can trigger dengue disease into actions that can prevent dengue disease that drains the water reservoir, manages household waste well, manages the used goods in the right way and puts the animal cage outdoors. In addition, dengue fever can be prevented by eradicating mosquito breeding and preventing mosquito bites. Growing mosquito breeding and preventing mosquito bites can be done with $3 \mathrm{M}$ plus movement.
\end{abstract}

Keywords: dengue fever, payaman village, citizen action, $3 \mathrm{M}$ plus

Abstrak: Demam Berdarah (DBD) disebabkan oleh virus dengue yang dibawah oleh nyamuk Aides Aigepty. Sejak tahun 2015 telah terjadi khasus DBD di Desa Payaman sebayak 3 orang dan 1 dari mereka tidak tertolong pada tahun 2016. Satu khasus dari penyakit DBD sudah merupakan Kejadian Luar Biasa dalam sektor kesehatan. Salah satu yang dapat memicu penyakit DBD adalah Angka Bebas Jentik yang rendah. Pemberantasan penyakit DBD dapat dilakukan dengan kegiatan Pemberantasan Sarang Nyamuk (PSN). Pada penelitian ini bertujuan untuk menganalisis tindakan warga desa yang dapat memicu penyakit DBD dan tindakan yang dapat mencegah penyakit DBD. Metode penelitian yang digunakan adalah deskripstif kuantitatif. Sumber data yang digunakan adalah data primer dan data sekunder. Data primer diambil dengan melakukan wawancara menggunakan kuisioner pada setiap rumah warga. Untuk mendukung kelengkapan data digunakan metode kualitatif dengan melakukan wawancara mendalam pada berbagai sektor yang terkait. Data sekunder diambil dari data Dasawisma Desa Payaman dan data Profil Desa. Hasil 
penelitian didapatkan bahwa Warga Desa Payaman khususnya RT 15-22 memiliki tindakan yang dapat memicu penyakit DBD, diantaranya penanganan kasus DBD yang terlambat, tidak menguras tempat penampungan air, pengelolaan sampah rumah tangga yang buruk, pengolaan barang bekas yang kurang tepat dan peletakkan kandang hewan di dalam rumah. Sedangkan tindakan yang dapat dimanfaatkan untuk mencegah penyakit Demam Berdarah yaitu memakai kelambu ketika tidur dan memelihara ikan pada tempat penampungan air. Perlu dilakukan perbaikan tindakan dengan merubah tindakan yang dapat memicu penyakit DBD menjadi tindakan yang dapat mencegah penyakit DBD yaitu menguras tempat penampungan air, mengelola sampah rumah tangga dengan baik, mengelola barang bekas dengan cara yang tepat dan meletakkan kandang hewan di luar rumah. Selain itu penyakit demam berdarah dapat dicegah dengan memberantas perkembangbiakan nyamuk dan mencegah gigitan nyamuk. Memberatas perkembang biakan nyamuk dan mencegah gigitan nyamuk dapat dilakukan dengan gerakan 3Mplus.

Kata kunci: demam berdarah, desa payaman, tindakan warga, 3M plus

\section{PENDAHULUAN}

Nyamuk merupakan salah satu hewan yang menjadi vector penyakit. Penyakit yang dapat disebabkan oleh gigitan nyamuk diantaranya; Penyakit Demam Berdarah Dengue, Penyakit Malaria, Penyakit Chikungunya, dan Penyakit Filariasis atau Kaki Gajah. Vektor utama penyakit DBD adalah nyamuk Aedes aegypti dan Aedes albopictus sebagai vektor sekunder (Depkes RI, 1997). Bila seseorang digigit oleh nyamuk yang membawa virus dengue maka dalam 4 - 7 hari kemudian akan timbul gejala DBD. Hampir seluruh wilayah di Indonesia merupakan daerah endemis penyakit DBD, kecuali pada daerah yang memiliki ketinggian lebih dari 1.000 meter di atas permukaan laut. Desa Payaman, merupakan salah satu daerah endemis penyakit DBD. Gejala DBD diantaranya demam tinggi, mual, muntah, ruam, sakit dan nyeri. Apabila timbul gejala manifestasi clinic maka harus segera ditangani, agar tidak menyebabkan kematian. Pada tahun 2015-2016 di Desa Payaman terdapat tiga kasus DBD, satu diantaranya meninggal pada tahun 2016.

Dalam perjalanan infeksi, terdapat tiga fase perjalanan infeksi dengue, yaitu diawali fase demam dimana viremia menyebabkan demam tinggi. Demam tinggi terjadi selama 2-7 hari dengan suhu tubuh dapat mencapai $40^{\circ} \mathrm{C}$, serta terjadi kejang demam. Dijumpai facial flush, muntah, nyeri kepala, nyeri otot dan sendi, nyeri tenggorok dengan faring hiperemis, nyeri di bawah lengkung tulang iga kanan, dan nyeri perut. Fase kedua yaitu fase kritis dimana terjadi perembesan plasma dengan derajat bervariasi pada efusi pleura dan asites.

Fase kedua diikuti dengan peningkatan hematokrit 10\%-20\% di atas nilai dasar, tanda perembesan plasma seperti efusi pleura dan asites, edema pada dinding kandung empedu, terjadi penurunan kadar albumin $>0.5 \mathrm{~g} / \mathrm{dL}$ dari nilai dasar / <3.5 g\% yang merupakan bukti tidak langsung dari tanda perembesan plasma. Pada usia anak-anak mengalami gelisah sampai terjadi penurunan kesadaran, sianosis, nafas cepat, nadi teraba lembut sampai tidak teraba; Hipotensi, tekanan nadi $\leq 20$ $\mathrm{mmHg}$, dengan peningkatan tekanan diastolik; Akral dingin, capillary refill time memanjang ( $>3$ detik); Diuresis menurun (< $1 \mathrm{ml} / \mathrm{kg}$ berat badan/jam), sampai anuria. Komplikasi akan terjadi apabila berupa asidosis metabolik, hipoksia, ketidakseimbangan elektrolit, kegagalan multipel organ, dan perdarahan hebat syok tidak dapat segera ditangani.

Fase ketiga yaitu fase recovery/ penyembuhan/ convalescence dimana perembesan plasma mendadak berhenti disertai reabsorpsi cairan dan ekstravasasi plasma. Fase penyembuhan juga ditandai dengan diuresis membaik dan nafsu makan kembali merupakan indikasi untuk 
menghentikan cairan pengganti. Gejala umum dapat ditemukan sinus bradikardia/ aritmia dan karakteristik confluent petechial rash seperti pada Demam Dengue. Derajat penyakit Demam Berdarah diaktegorikan ke dalam empat tingkatan derajat, diantaranya dengan ciriciri sebagai berikut; Derajat I dengan ciri demam disertai gejala tidak khas dan satu-satunya manifestasi perdarahan ialah uji bending; Derajat II dengan ciri seperti derajat I, disertai perdarahan spontan di kulit dan atau perdarahan lain; Derajat III dengan ciri didapatkan kegagalan sirkulasi, yaitu nadi cepat dan lambat, tekanan nadi menurun $(\leq 20 \mathrm{mmHg})$ atau hipotensi, sianosis di sekitar mulut, kulit dingin dan lembap dan anak tampak gelisah; dan Derajat IV dengan ciri syok berat (profound shock), nadi tidak dapat diraba dan tekanan darah tidak terukur.

Perkembangbiakan nyamuk terjadi selama 10-12 hari setelah telur menetas. Nyamuk dapat menetaskan telurnya di air yang bersih atau tempat yang lembap. Beberapa tempat yang dapat menjadi tempat bertelurnya nyamuk Aides Aegypti yaitu ban kendaraan bekas yang berisi air, pohon dengan lubang pada batangnya, toilet, pot tanaman, tempat minum hewan peliharaan, vas, kolam renang, tempat sampah, dll. Telur tersebut akan tumbuh menjadi jentik nyamuk. Jentik adalah tahap larva dari nyamuk yang fase hidupnya di dalam air. Jentik hidup di air dan memiliki perilaku menggantung pada permukaan air untuk bernapas. Setelah fase jentik terlewati nyamuk akan menetas dan tumbuh menjadi nyamuk dewasa. Nyamuk dewasa suka dengan tempat yang gelap, dan lembap. Beberapa tempat yang dapat menjadi sarang nyamuk yaitu hutan, rawa, gantungan baju, selokan, kumpulan barang bekas, dan gudang.

Jentik menjadi sasaran dalam pengendalian populasi nyamuk. Angka Bebas Jentik atau desebut juga Larva Free Index adalah persentase rumah dan atau tempat umum yang tidak ditemukan jentik pada pemeriksaan jentik. Angka Bebas Jentik menunjukkan jumlah tempat yang bebas jentik pada suatu daerah.
Angka Bebas Jentik yang tinggi menunjukkan suatu daerah tersebut terdapat sedikit jentik, sedangkan Angka Bebas Jentik yang rendah menunjukkan masih banyak nya jentik di wilayah tersebut. Wilayah yang memiliki Angka Bebas Jentik rendah akan berisiko menjadi wilayah endemik penyakit akibat nyamuk seperti Demam Berdarah Dengue dan penyakit akibat gigitan nyamuk lainnya. Desa Payaman memiliki Angka Bebas Jentik yang rendah. Penyakit DBD pada Desa Payaman dapat dimungkinkan karena angka bebas jentik yang redah, yaitu hanya $11,3 \%$ tempat penampungan air yang tidak mengandung jentik. Keberhasilan kegiatan PSN dapat diukur dengan Angka Bebas Jentik (ABJ), Apabilah ABJ lebih atau sama dengan 95\% diharapkan penularan penyakit DBD dapat dicegah atau dikurangi (Depkes RI, 2010: 2). Kegiatan Pemberantasan Sarang Nyamuk (PSN) dapat dilakukan dengan cara 3Mplus. Adapun yang dimaksud dengan 3M Plus adalah menguras tempat penampungan air, menutup tempat penampungan air, dan mengubur barang bekas, selain itu juga melakukan pencegahan perkembang biakan nyamuk lainnya seperti menaburkan bubuk larvasida pada tempat penampungan air yang sulit dibersihkan; menggunakan obat nyamuk atau anti nyamuk; menggunakan kelambu saat tidur; memelihara ikan pemangsa jentik nyamuk; menanam tanaman pengusir nyamuk, mengatur cahaya dan ventilasi dalam rumah; menghindari kebiasaan menggantung pakaian di dalam rumah yang bisa menjadi tempat istirahat nyamuk, dan lain-lain. Selain PSN 3M Plus, sejak Juni 2015 Kemenkes sudah mengenalkan program 1 rumah 1 Jumantik (juru pemantau jentik) untuk menurunkan angka kematian dan kesakitan akibat Demam Berdarah Dengue. Gerakan ini merupakan salah satu upaya preventif mencegah Demam Berdarah Dengue (DBD).

Satu khasus DBD di suatu tempat merupakan Kejadian Luar Biasa pada sektor kesehatan. Terjadinya KLB DBD di Indonesia berhubungan dengan 
berbagai faktor risiko, yaitu; Lingkungan yang masih kondusif untuk terjadinya tempat perindukan nyamuk Aedes; Pemahaman masyarakat yang masih terbatas mengenai pentingnya pemberantasan sarang nyamuk (PSN) $3 \mathrm{M}$ Plus; Perluasan daerah endemic akibat perubahan dan manipulasi lingkungan yang terjadi karena urbanisasi dan pembangunan tempat pemukiman baru; serta meningkatnya mobilitas penduduk. Perilaku kesehatan warga mempengaruhi kondisi kesehatan. Sesuai yang dinyatakan oleh Soelita Sarwono bahwa perilaku kesehatan adalah segala bentuk pengalaman dan interaksi individu dengan lingkungannya khususnya menyangkut pengetahuan dan sikap tentang kesehatan serta tindakannya yang berhubungan dengan kesehatan dan penyakit. Apabila warga berperilaku sehat maka kondisi kesehatannya juga akan sehat, begitu sebaliknya warga berperilaku tidak sehat maka akan mendatangkan penyakit. Penelitian ini bertujuan untuk pencegahan penyakit DBD di Desa Payaman. Oleh karena itu tujuan dalam penelitian ini adalah menganalisis tindakan warga untuk mencegah penyakit DBD. Dalam Penelitian ini akan diteliti mengenai tindakan warga Desa Payaman yang dapat menyebabkan penyakit DBD dan tindakan warga Desa Payaman yang dapat mencegah penyakit DBD berdasarkan studi deskriptif analitik yang telah dilakukan oleh peneliti di wilayah RT 1522 Desa Payaman, Kabupaten Bojonegoro, Jawa Timur.

\section{METODE}

Metode penelitian yang digunakan adalah penelitian observasional. Jenis data yang digunakan adalah data primer dan data sekunder. Data primer diperoleh melalui pendekatan kuantitatif yaitu melakukan wawancara dengan menggunakan instrumen kuesioner dan indeks rekapitulasi keluarga sehat pada setiap rumah di RT 15-22 Desa Payaman. Selain itu juga dilakukan pengambilan data primer melalui pendekatan kualitatif dengan melakukan FGD, wawancara, wawancara mendalam (indept interview), dan pengamatan. Selain itu data sekunder di dapat dengan analisis dokumen. Beberapa data sekunder yang digunakan referensi diantaranya yaitu data dari Ponkesdes, Puskesmas, perangkat desa, Dasawisma, PKK serta Posyandu. Besar sampel ditentukan menggunakan metode sampling acak bertingkat/strata, sehingga diperoleh sampel sebanyak 221 dari 308 KK. Sasaran dalam penelitian ini adalah anggota keluarga yang tergolong pada usia remaja-lansia yaitu umur 15-70 tahun. Kelompok umur tersebut diambil dikarenakan usia bayi, balita, dan anakanak atau <15 tahun dianggap belum memiliki pengetahuan yang cukup untuk menjawab soal yang terdapat pada kuisioner dan indeks keluarga sehat. Peneliti memilih tempat tinggal di rumah Kepala Dusun Tiggang karena lokasi tersebut dekat dengan akses fasilits kesehatan yang bertujuan untuk mempermudah observasi.

Tahapan penelitian yang dilakukan yaitu, pertama mendefinisikan masalah yang dialami oleh warga Desa Payaman. Pendefinisian ini dilakukan dengan metode Focus Group Discussion. Focus Group Discussion (FGD) merupakan metode dengan cara mengumpulkan warga untuk diminta pendapatnya mengenai masalah yang di alami. Kedua menyusun rencana penelitian, langkah ini diisi dengan membuat pertanyaan dalam kuesioner berdasarkan atas masalah yang menjadi prioritas dari kegiatan FGD dengan warga. Ditemukan masalah mengenai penyakit DBD yang menjadi masalah dalam satu tahun terakhir. Selain menyusun kuisioner, pada kangkah kedua juga menentukan jadwal diskusi dengan warga dan melakukan jadwal observasi untuk berkeliling RT 15-22 Desa Payaman. Ketiga, Mengumpulkan data, pegambilan data dilakukan dengan mengunjungi rumah setiap warga. Kegiatan mengunjungi rumah dilakukan dengan membacakan soal yang ada di kueisoner dan indeks keluarga sehat serta melakukan observasi terhadap kondisi rumah dan tempat penampungan air. Penyebaran kuesioner dilakukan setiap hari dimulai pukul 08.00 WIB sampai 
12.00 WIB kemudian dilanjutkan kembali pukul 15.00 WIB sampai 17.30 WIB. Dalam Kuesioner tersebut berisi pertanyaan mengenai indeks keluarga sehat yang sudah ditentukan standar nya oleh Dinas Kesehatan Kota, dan pertayaan mengenai tindakan yang menyebabkan penyakit DBD di luar pertanyaan indeks keluarga sehat.

Indept Interview dilakukan pada tanggal 22 Juli 2016 dengan melakukan wawancara kepada perangkat desa, kader cakupan RT 15 sampai 22 (Tinggang Lor, Tinggang Selatan dan Ketawang), Tokoh masyarakat, serta pihak Ponkesdes dan Puskesmas. Sedangkan data sekunder dilakukan dengan analisis dokumen yang dimiliki oleh Desa Payaman. Keempat, melakukan analisis data dan interpretasi data. Terakhir yaitu bebagi pandangan untuk menemukan upaya yang cocok dalam menanggulangi masalah DBD yang menjangkit Desa Payaman setahun terakhir.

\section{HASIL dan PEMBAHASAN}

Selama 35 hari peneliti telah melakukan pengumpulan data dan pengamatan. Berikut akan dideskripsikan dan dibahas tentang demografi Desa Payaman, tindakan tidak sehat warga yang dapat menyebabkan penyakit DBD dan tindakan sehat yang dapat mencegah penyakit DBD.

\section{Demografi Desa Payaman}

Desa Payaman terletak di Kecamatan Ngraho, Kabupaten Bojonegoro berdampingan dengan Kecamatan Padangan yang berbatasan langsung dengan batas Provinsi Jawa Tengah yaitu
Kabupaten Blora. Jarak antara Desa Payaman dengan pintu masuk Provinsi Jawa Tengah sejauh 15 KM. Secara geografis, Desa Payaman terletak pada $7^{\circ} 21^{\prime}-7^{\circ} 31^{\prime}$ Lintang Selatan dan $110^{\circ} 10^{\prime}$ $111^{\circ} 40^{\prime}$ Bujur Timur. Topografi ketinggian desa ini adalah berupa daratan sedang, yaitu sekitar 29 (mdpl) di atas permukaan air laut. Menurut data BPS Kabupaten Bojonegoro tahun 2014, curah hujan Desa Payaman rata-rata mencapai $2.400 \mathrm{~mm}$. Sedangkan luas wilayah Desa Payaman adalah 326.086 Ha. Desa Payaman sebagian besar adalah wilayah hutan jati, di mana kondisi batang dari pohon jati tersebut sudah meninggi. Pemukiman penduduk tersebar luas dengan jarak berjauhan. Pemukiman penduduk berjarak berjauhan dikarenakan sebagian besar wilayah desa adalah hutan jati. Namun ada beberapa warga yang lokasi rumahnya berada di dalam hutan jati. Hutan merupakan salah satu ekositem nyamuk, Sehingga populasi nyamuk di Desa Payaman sangatlah besar. Desa Payaman RT 17-19 terletak dipinggir jalan raya, RT 20-22 terletak di dalam hutan dan RT 15-16 terletak di jalan menuju balai desa. Kepala Desa yang menjabat pada periode ini yaitu bapak Sofyan. Bapak Sofyan sosok pemimpin yang peduli dengan warganya. Bapak Sofyan juga peduli akan program kesehatan yang dirancang untuk desa. Hal ini akan menjadi potensi untuk melakukan program kesehatan yang dapat berpotensi mencegah penyakit DBD.

Berikut akan dipaparkan hasil demografi warga Desa Payaman RT 15-22 berdasarkan jenis kelamin, usia, pekerjaan dan tingkat pendidikan.

a) Kelompok Usia dan Jenis Kelamin 
Tabel 1. Jumlah Penduduk Desa Payaman Tahun 2016 menurut Kelompok Usia dan Jenis Kelamin

\begin{tabular}{ccccc}
\hline Usia & \multicolumn{3}{c}{ Jenis Kelamin } \\
\cline { 2 - 5 } & \multicolumn{2}{c}{ Laki-laki } & $\mathbf{N}$ & Perempuan \\
\cline { 2 - 5 } & $\mathbf{N}$ & 0.05 & 6 & \% \\
\hline 0-11 bulan & 4 & 2.03 & 23 & 0.87 \\
12-59 bulan & 14 & 18.9 & 99 & 3.34 \\
5-14 tahun & 130 & 27.21 & 224 & 14.41 \\
>= 15 tahun & 187 & 48.19 & 352 & 32.60 \\
\hline Total & 335 & & 51.22
\end{tabular}

Berdasarkan tabel 1 dapat disimpulkan bahwa Mmayoritas penduduk RT 15-22 Desa Payaman memiliki jenis kelamin perempuan yaitu sebesar $51,22 \%$ dari 687 jiwa selain itu menurut usia, penduduk cenderung pada kategori dewasa $(>=15$ tahun) yaitu sebesar 411 orang dari 687 orang. Namun jumlah warga yang berusia anak-anak juga banyak, hal tersebut dapat dimungkinkan timbulnya penyakit DBD, sebab kebanyakan DBD menyerang usia anak-anak dengan kondisi tubuh yang rentan.

\section{a) Pekerjaan}

Warga Desa Payaman memiliki jenis pekerjaan yang beraneka ragam. Pekerjaan tersebut bukanlah pekerjaan utama, namun beberapa diantaranya memiliki pekerjaan lain untuk menambah pemasukan keuangan keluarga. Berikut akan diasajikan mengenai distribusi jenis pekerjaan pada Tabel 2 .

Tabel 2. Distribusi Jenis Pekerjaan Penduduk Desa Payaman Tahun 2016

\begin{tabular}{|c|c|c|}
\hline Pekerjaan & $\mathbf{N}$ & $\%$ \\
\hline$\overline{\mathrm{PNS}}$ & 8 & 1.16 \\
\hline TNI & 1 & 0.14 \\
\hline Pedagang & 105 & 15.2 \\
\hline Pengusaha Barang dan Jasa & 33 & 4.8 \\
\hline Guru/Dosen & 9 & 1.31 \\
\hline Pensiun & 7 & 1.01 \\
\hline Pekerjaan & $\mathrm{N}$ & $\%$ \\
\hline Aparatur Pemerintah Desa & 4 & 0.58 \\
\hline Petani & 101 & 14.7 \\
\hline Ibu Rumah Tangga & 74 & 10.77 \\
\hline Pegawai & 24 & 3.49 \\
\hline Belum/Tidak Bekerja & 201 & 29.2 \\
\hline Total & 687 & 100 \\
\hline
\end{tabular}

Berdasarkan tabel 2 dapat disimpulkan bahwa sebagian besar warga Desa payaman bermata pencaharian sebagi pedagang, dan petani. Pertanian merupakan hal yang penting bagi sebagian warga desa. Ketika musim panen tiba tidak sedikit warga mengajak anaknya untuk membantu memanen hasil tanam. Kegiatan berdagang dan petani merupakan pekerjaan yang berada di luar ruangan, sehingga sangat memungkinkan unytuk digigit nyamuk aides ketika sedang bekerja.

\section{b) Tingkat pendidikan}

Tingkat pendidikan warga dimulai dari tidak pernah sekolah sampai dengan perguruan tinggi. Berikut akan disajikan tingkat pendidikan warga desa pada tabel 4

Tabel 3. Distribusi Penduduk Desa Payaman Tahun 2016 berdasarkan Tingkat Pendidikan

\begin{tabular}{lcc}
\hline \multicolumn{1}{c}{ Pendidikan } & N & \% \\
\hline Belum Sekolah & 76 & $\mathbf{1 2}$ \\
Tidak tamat SD & 47 & 7,3 \\
Tamat SD & 267 & 41,6 \\
SLTP/sederajat & 120 & 18,7 \\
SLTA/sederajat & 102 & 15,9 \\
Diploma I/II & 3 & 0,46 \\
Akademi/Diploma & 5 & 0,78 \\
III/Sarjana Muda & & \\
Diploma IV/ S1 & 21 & 3,27 \\
Sastra II & 1 & 0,16 \\
\hline \multicolumn{1}{c}{ Total } & 642 & $100 \%$ \\
\hline \multicolumn{1}{c}{}
\end{tabular}

Berdasarkan tabel 3 dapat disimpulkan bahwa warga desa sebagian besar memiliki tingkat pendidikan sampai sekolah dasar (SD). Beberapa mencapai perguruan tinggi namun banyak juga yang belum sekolah 
atau tidak tamat SD. Kondisi tersebut dapat memungkinkan kurangnya pengetahuan warga mengenai penyakit DBD, pengetahuan tersebut yang menjadi dasar mereka bertindak.

Desa Payaman memiliki satu Ponkesdes, dan 5. Pos kesehatan tersebar rata di wilayah Desa yang terdiri dari empat Dusun. Dusun yang ada di Desa Payaman diantaranya Dusun Tinggang, Dusun Merbong, Dusun Payaman dan Dusun Ketawang. Letak Ponkesdes berada di lokasi yang sama dengan Balai Desa Payaman. Ponkesdes Desa Payaman terdiri dari satu Bidan dan satu perawat. Bidan desa yang bertugas di Ponkesdes tersebut tinggal dan menetap di dalam Ponkesdes. Menurut keterangan perawat yang bekerja di Ponkesdes Payaman, Ponkesdes berdiri pada tahun 2012. Yang sebelumnya merupakan polindes pada tahun 2008. Jumlah tenaga kerja sebanyak empat orang dengan jam kerja Senin s/d Jum'at. Cakupan wilayah kerja satu desa dengan rincian empat dusun, $22 \mathrm{RT}$ dan $930 \mathrm{KK}$.

Regenerasi kader kesehatan dirasa sulit, namun sejak sekarang Desa Payaman dipimpin oleh seorang Kepala Desa yang memiliki sifat lebih bersahabat, sehingga regenarasi kader dirasa lebih mudah sebab istri Kepala Desa lebih dekat dengan masyarakat, sehingga lebih mudah memilih seseorang untuk menjadi kader. Saat ini jumlah kader di Payaman sudah mencukupi yakni terdapat 5 kader pada setiap pos. Kader kesehatan pada setiap pos berjumlah lima orang. Sedangkan intensif yang didapat oleh kader sejumlah Rp. 10.000/bulan yang diberikan pada akhir tahun. Intensif tersebut sudah direncanakan dan disetujui untuk dinaikkan menjadi Rp. 30.000 namun belum terealisasikan. Insentif kader tersebut diambilkan dari Anggaran Dana Desa. Semua kader aktif mengadakan pertemuan setiap tanggal 1 dan 15 per bulannya. Selain mengadakan pertemuan rutin, para kader juga aktif menjemput warga yang harus ke posyandu untuk memantau kesehatan balita dan lansia.

Kegiatan Pemberantasan Sarang Nyamuk telah dibantu oleh Anggaran
Dana Desa. Untuk kegiatan Pemberantasan Sarang Nyamuk (PSN) dilakukan fogging, fogging dapat dilakukan lebih dari sekali selama satu tahun. Fogging dapat dilakukan apabila ditemukan satu kasus positif penyakit akibat nyamuk dan 3 orang mengalami suhu badan tinggi.

\section{Tindakan warga yang dapat menimbulkan penyakit DBD}

Berikut akan dipaparkan mengenai tidakan warga yang dapat menyebabkan datangnya penyakit DBD di Desa Payaman.

\section{a. Penanganan kasus DBD yang terlambat}

Desa Payaman berada pada daerah endemi, berdasarkan data insiden penyakit akibat nyamuk ponkesdes didapat bahwa selama tiga tahun terakhir sejak tahun 2014 terjadi 20 kasus penyakit Chikungunya, 1 khasus DBD pada tahun 2015 dan 3 kasus DBD pada tahun 2016. Pada tahun 2016 terjadi khasus meninggal akibat penyakit DBD karena penolongan yang terlambat. Berdasarkan keterangan dari bidan desa, adanya kasus DBD tidak segera teridentifikasi, sehingga terjadi keterlambatan penolongan pada tahun 2016. Upaya fogging hanya akan dilakukan ketika sudah ada temuan kasus DBD. Penyakit DBD merupakan penyakit yang dapat mengancam nyawa seseorang bahkan nyawa orang orang yang ada di sekitarmya. Satu kasus yang menunjukkan manifestasi klinis harus segera ditangani, karena apabila terlambat akan menyebabkan kematian dan dapat menular ke orang lain. Satu temuan kasus DBD sudah merupakan Kejadian Luar Biasa (KLB) bagi aspek kesehatan. Berdasarkan hasil wawancara dengan kader dan bidan desa upaya penanggulangan DBD yang telah dilakukan di Desa Payaman hingga saat ini adalah fogging atau pengasapan. Fogging ini dilakukan di tempat-tempat yang sekiranya menjadi sarang nyamuk dewasa ketika terjadi kasus. Namun fogging hanya dapat membunuh nyamuk dewasa, sedangkan jentik nyamuk tidak ikut terbunuh. 


\section{b. Tidak menguras tempat penampungan air}

Salah satu tempat perkembangan nyamuk adalah tempat penampungan air. Nyamuk akan menetaskan telurnya di atas permukaan air, kemudian telur akan berkembang menjadi jentik di dalam air tersebut. Tempat penampungan air diantaranya adalah bak kamar mandi, gentong air minum, kolam ikan dan tempat yang berisi air lainnya. Berdasarkan observasi terhadap rumah warga masih ditemukan angka bebas jentik yang tinggi. seperti. Untuk mencegah perkembangan jentik tersebut hendaklah dengan menutup tempat penampungan air dan mengurasnya secara rutin, berikut akan disajikan data mengenai frekuensi pengurasan tempat penampungan air oleh warga RT 15-22 Desa Payaman pada tabel 4.

Tabel 4. Disribusi Frekuensi Pengurasan Bak Mandi di Setiap Rumah Warga Desa Payaman Tahun 2016

\begin{tabular}{|l|l|}
\hline Frekuensi menguras & Persentase \\
\hline Semingu sekali & $61.5 \%$ \\
\hline Lebih dari semingu & $38.5 \%$ \\
\hline Total & $\mathbf{1 0 0 \%}$ \\
\hline
\end{tabular}

Berdasarkan tabel 4 dapat disimpulkan bahwa masih banyak warga yang belum menyadari pentingnya menguras tempat penampungan air seperti bak mandi, bahkan banyak warga yang tidak mengetahui behawa tempat penampungan airnya mengandung jentik nyamuk. Pengurasan dengan frekuensi satu minggu sekali berdasarkan atas perkembangan jentik nyamuk yang dapat berlangsung selama 10-12 hari sampai menjadi nyamuk dewasa. Kurangnya kesadaran dalam menguras tempat penampungan air secara rutin mungkin menjadi salah satu penyebab munculnya penyakit DBD. Keaktifan kader dapat dimanfaatkan untuk menambah program pemantauan jentik di rumah rumah warga. Dengan segera berlakunya intensif kader menjadi 30.000/bulan diharapkan program pemantauan jentik dapat berjalan dan efektif meningkatkan angka bebas jentik.

\section{c. Pengelolaan sampah rumah tangga yang buruk}

Tindakan pengolahan sampah rumah tangga yang tidak benar dapat menjadi sarang nyamuk. Berdasarkan data yang didapatkan dari RT 15 sampai 22 diketahui bahwa kegiatan sanitasi lingkungan seperti pemisahan sampah belum berjalan maksimal. Cara warga dalam mengolah sampah diantaranya yaitu dibakar, ditimbun dan dibuang ke sungai. Berikut akan disajikan data mengenai frekuensi tindakan warga berdasarkan cara pengolahan sampah rumah tangga yang akan disajikan pada tabel 5 berikut ini.

Tabel 5. Distribusi pengolaan sampah oleh warga RT 15-22 di Desa Payaman Tahun 2016

\begin{tabular}{|l|r|}
\hline Jenis Penanganan Sampah & \multicolumn{1}{|l|}{$\%$} \\
\hline Dibakar & $83.7 \%$ \\
\hline Ditimbun & $5.9 \%$ \\
\hline Dibuang ke sungai & $10.4 \%$ \\
\hline Total & $\mathbf{1 0 0 \%}$ \\
\hline
\end{tabular}

Berdasarkan tabel 5 dapat disimpulkan bahwa sebagian besar warga Desa Payaman mengolah sampah dengan cara dibakar. Tindakan membakar sampah di sini tidak langsung dilakukan, tetapi menunggu sampah yang terkumpul banyak dan cukup untuk dibakar. Selang waktu menunggu tersebut dengan membiarkan sampah diletakkan di tempat terbuka dan terkena hujan, kondisi tersebut dapat dijadikan nyamuk untuk menetaskan telurnya, dan apabila sampai dengan 12 hari tidak diolah maka telur nyamuk tersebut akan berubah menjadi nyamuk dewasa dan menambah populasi nyamuk di Desa Payaman. Warga desa lebih cenderung membakar sampah dikarenakan alasan mereka memiliki lahan yang luas untuk tempat sampah terbuka hingga menunggu penuh cukup untuk dibakar. Mereka lebih memilih mengumpulkan sampah di lahan terbuka dari pada menyediakan tempat sampah yang tertutup. Hal ini berbeda dengan penduduk kota yang tidak banyak memiliki lahan 
luas sehingga mereka lebih memilih meletakkan sampah pada tempat sampah.

\section{d. Pengolaan barang bekas yang kurang tepat}

Selain tidak sadar akan menguras tempat penampungan air masyarakat Desa Payaman juga mempunyai kebiasaan mengumpulkan barang bekas untuk dijual ke tukang rosokan. Terdapat 87 warga yang mengumpulkan barang bekas untuk dijual ke tukang rosokan. Barang-barang yang dikumpulkan tersebut apabila terkena air hujan dapat menjadi sarang nyamuk. Penjualan barang bekas memang menghasilkan uang, namun alangkah lebih bernilai ekonomis apabila barang-barang tersebut diolah menjadi barang yang lebih memiliki nilai jual. Selain menambah nilai jual kegiatan mengolah barang bekas juga dapat mengisi waktu luang sehari-hari dan meningkatkan kreatifitas warga. Oleh karena itu perlu untuk mengelola tempat pengumpulan barang bekas di tiap rumah. Agar tidak menjadi sarang nyamuk hendak nya barang bekas diletakkan pada tempat yang kering dan tertutup.

\section{e. Peletakan kandang hewan di dalam rumah}

Tindakan yang dapat menimbulkan penyakit DBD lainnya adalah meletakkan kandang hewan ternak di dalam rumah. Tidak sedikit warga yang letak tempat tidurnya dekat dengan kandang hewan, karena mereka meletakkan kandang hewan di dalam rumah. Ditemukan 52 dari 221 rumah yang lokasi kandang hewannya berada di dalam rumah. Hal tersebut dapat memicu sarang nyamuk pindah ke dalam rumah. Nyamuk suka menggigit hewan ternak seperti sapi atau kambing, jika kandang hewan ternak di letakkan di dalam rumah maka kemungkinan besar nyamuk juga akan ikut masuk ke dalam rumah, sehingga sangat mungkin untuk menyerang manusia yang ada di sekitarnya. Idealnya kandang hewan ternak dilokasikan dengan jarak $10 \mathrm{~m}$ dari rumah. hal tersebut untuk menghindari gigitan nyamuk yang mulanya menyerang hewan ternak berubah menjadi menyerang manusia.

\section{Tindakan yang dapat mencegah penyakit DBD}

Warga Desa Payaman juga memiliki tindakan yang dapat mencegah penyakit DBD. Berikut akan dipaparkan tindakan warga desa.

\section{a. Penggunaan kelambu saat tidur}

Tindakan yang dapat mencegah penyakit DBD adalah penggunaan kelambu ketika tidur. Karena penggunaan kelambu ketika tidur dapat mencegah dari gigitan nyamuk. Berikut akan disajikan persentase warga yang menggunakan kelambu saat tidur pada tabel 6 .

Tabel 6. Distribusi Pemaikaian Kelambu Saat Tidur di RT 15-22 Desa Payaman Tahun 2016

\begin{tabular}{|l|l|}
\hline Perilaku Warga & Persentase \\
\hline $\begin{array}{l}\text { Tidur menggunakan } \\
\text { kelambu }\end{array}$ & $52,9 \%$ \\
\hline Tidur tanpa kelambu & $47,1 \%$ \\
\hline Total & $\mathbf{1 0 0 \%}$ \\
\hline
\end{tabular}

Sumber Data Primer Tahun 2016

Dari tabel 6 dapat disimpulkan masih banyak warga yang tidak menggunakan kelambu saat tidur. Namun warga yang menggunakan kelambu lebih banyak daripada yang tidak menggunaan kelambu. Tidur menggunakan kelambu merupakan perilaku hidup sehat yang dapat mencegah penyakit DBD. Nyamuk tidak dapat menembus jaring jaring kelambu yang ukurannya lebih kecil dari ukuran tubuh nyamuk. Banyak warga yang tidak menggunakan kelambu karena memiliki alasan sukar apabila menggunakan kelambu, sehingga tidur tidak nyaman.

\section{b. Pemeliharaan ikan pada tempat bak mandi}

Tindakan sehat lain dalam mencegah penyakit DBD yaitu pemeliharaan ikan pada bak mandi. Warga desa banyak yang memelihara ikan di dalam bak mandi rumah nya. Ditemukan 15 dari 221 rumah memelihara ikan pada bak kamar mandinya. Warga yang memelihara ikan pada bak mandi biasanya memiliki alasan 
karena malas menguras bak mandi yang ukurannya besar. Tindakan memelihara ikan di dalam bak mandi dapat mencegah timbulnya penyakit $\mathrm{DBD}$, sebab dengan memelihara ikan pada bak mandi, ikan tersebut akan memakan jentik sebelum berkembang menjadi nyamuk, sehingga rantai perkembangbiakan nyamuk akan terputus. Namun warga harus tetap memperhatikan tempat penampungan air lain seperti gentong air minum atau gentong air untuk masak dengan cara menutupnya dan mengurasnya setiap satu minggu sekali.

\section{Upaya pencegahan DBD berdasarkan tindakan warga}

Beberapa alternatif solusi untuk mengatasi penyakit DBD yang dianalisis dari tindakan warga Desa Payaman, diantaranya adalah;

1. Kerja bakti membersihkan saluran air; Dengan membersihkan saluran air diharapkan dapat memperlancar saluran air sehingga tidak terjadi genangan air yang dapat dijadikan daur hidup nyamuk.

2. pembentukan Jumantik;

Pembentukan jumantik diharapkan dapat memantau pertumbuhan jentik nyamuk di rumah warga. Juru pemantau jentik dapat dibentuk dari kader kesehatan atau juga remaja desa yang turut aktif membangun desa.

3. Pembagian bubuk abate

Pembagian bubuk abate dapat diberikan dengan bantuan Jumantik, ketika memantau rumah warga Jumatik dapat sekaligus membagikan bubuk abate dan menjelaskan kepada warga manfaat dan cara penggunaan bubuk abate.

4. Penyuluhan kepada masyarakat Penyuluhan dapat dilakukan saat posyandu lansia, balita dan remaja. Setiap kelompok usia bertanggung jawab atas kesehatan rumah nya, khususnya memantau jentik di rumah. walaupun sudah terbentuk Jumantik, namun setiap warga bertanggung jawab atas pertumbuhan jentik di rumahnya. Selain itu untuk pencegahan juga diperlukan sosialisasi untuk meningkatkan tindakan warga yang dapat mencegah penyakit DBD dan meningkatkan angka bebas jentik yaitu, selalu waspada dan memperhatikan geraka $3 \mathrm{M}$ plus.
1. Menguras tempat penampungan air secara rutin

2. Menutup tempat penampungan air

3. Mengubur atau mendaur ulang barangbarang bekas dan tidak meletakkan secara terbuka

4. Mengumpulkan sampah pada tempat sampah yang tertutup

5. Menggunakan obat anti nyamuk

6. Menggunakan pakaian lengan panjang untuk menghindari gigitan nyamuk

7. Memakai kelambu ketika tidur

8. Menebar bubuk abate pada tempat penampungan air

9. Memelihara ikan pada tempat penampungan air untuk membunuh jentik-jentik

10. Meletakkan kandang hewan ternak di luar rumah

11. Dan selalu memantau perkembangan jentik nyamuk setiap seminggu sekali di seluruh tempat penampungan air

Selain itu dengan adanya program dari Pemerintah Pusat Bojonegoro yaitu Desa Siaga dapat menjadi peluang untuk memberantas masalah angka bebas jentik yang masih rendah. Sumber daya Ponkesdes yang mumpuni dan adanya program Desa Cerdas Desa Pintar di Kabupaten Bojonegoro dapat dimanfaatkan untuk memperbaiki kelemahan yang ada di Desa Payaman. Misalnya Kader Kesehatan di Ponkesdes dapat diberdayakan sebagai Pemantau jentik.

Peran Dinas Kesehatan adalah sebagai regulator dan pemegang kebijakan selain berfungsi pula dalam monitoring dan evaluasi kegiatan sedangkan pelaksana kegiatan adalah puskesmas melalui Ponkesdes.

\section{SIMPULAN}

Dalam menanggulangi penyakit DBD yang terjadi di Desa Payaman dalam satu terakhir ini dapat dilakukan oleh warga dengan memanfaatkan potensi desa, sumber daya dan tindakan yang biasa dilakukan oleh masyarakat desa. Dengan meningkatkan Angka Bebas Jentik yang merupakan penyebab paling dominan diharapkan Desa Payaman terhindar dari 
penyakit akibat nyamuk, khususnya penyakit DBD. Tindakan warga yang dapat menyebabkan penyakit DBD diantaranya; penanganan penyakit DBD yang terlambat, tidak menguras kamar mandi, pengolaan sampah rumah tangga yang buruk, pengolaan barang bekas yang kurang tepat, dan peletakkan kandang hewan di dalam rumah. sedangkan tindakan warga yang dapat mencegah penyakit DBD diantaranya; tidur menggunakan kelambu dan memelihara ikan di dalam bak mandi.

Berdasarkan telaat peneliti, pencegahan perkembangbiakan nyamuk dapat dilakukan dengan melakuan kerja bakti, pembentukan jumatik. Pembentukan jumantik berguna untuk mengkoordinasi pemantauan jentik disetiap penampungan air baik di rumah, sekolah, mushola, TPQ maupun balai desa. Pencegahan perkembang biakan nyamuk juga dilakukan dengan pembagian bubuk abate, dan penyuluhan kepada warga dengan selalau memperhatikan kegiatan 3Mplus yaitu menguras, menutp tempat penampungan air, mengubur atau mengolah barang bekas. Selain memantau perkembangbiakan nyamuk dapat juga dilakukan dengan menghindari gigitan nyamuk dengan memakai kelambu ketika tidur dan memisahkan kandang hewan ternak dari rumah. Perlu dilakukan penyuluhan mengenai upaya meningkatkan angka bebas jentik pada posyandu lansia, balita dan remaja dengan memanfaatkan keaktifan bidan desa, perawat dan kader kesehatan. Karena dibutuhkan kesadaran dari setiap warga untuk bertanggung jawab atas angka bebas jentik di rumah masingmasing.

\section{DAFTAR PUSTAKA}

Anupong S, et all, Trasmission of Dengue Haemorrhagic Fever: At Home or School, Dengue Bulletin, Vol, 29, 2005.

Canyon D. 2000. Advances in Aedes aegypti Biodynamis and Vector Capacity: Tropical Infectious and Parasitic Diseases Unit, School of Public Health and Tropical Medicine, James Cook University

Gubler DJ. Epidemic Dengue Hemorrhagic Fever as a Public Health, Sosial and
Economic Problem in Tha 21st Century. Trends Microbiol. 2002; Vol. 10: p. 100104

Hadinegoro, Rezeki S, Soegianto S, Soeroso T, Waryadi S. Tata Laksana Demam Berdarah Dengue di Indonesia. Jakarta: Ditjen PPM\&PL Depkes\&Kesos R.I; 2001.

Hasyimi dan Mardjan S, pengamatan Tempat Perindukan Aedes Aegypti pada Tempat Pengampungan Air Rumah Tangga Pada masyarakat Pengguna Air Olahan, Jurnal Ekologi Kesehatan, Vol 391) April 2004: 37-42.

Jane, Pangemanan, Nelwan Jeini. 2011. Perilaku Masyarakat Tentang Program Pemberantasan Penyakit DBD di Kabupaten Minahasa Utara. Universitas Sam Ratulangi, Manado

Noor R. Nyamuk Aedes aegypti. 2009 [cited 24 Desember 2010]; Available from:http://id.shvoong.com/medicine andhealth/epidemiology-publichealth/ 2066459-nyamuk-aedes-aegypti.

Notoatmodjo S. 2003. Pendidikan dan Perilaku Kesehatan. Jakarta : PT Rhineka Cipta. Hlm 114-117

Novriani H. Respon Imun dan Derajat Kesakitan Demam Berdarah Dengue dan Dengue Syndrome Pada Anak. Cermin Dunia Kedokteran. 2002; Vol 134:46-9.

Kementrian Kesehatan RI. 2010. Demam Berdarah Dengue. Buletin Jendela Epidemiologi. Vol 2. ISSN-2087-1546. Pusat Data dan Surveilans Epidemiologi Kementrian Kesehatan.

Lestari K. Epidemiologi Dan Pencegahan Demam Berdarah Dengue (DBD) Di Indonesia. Farmaka. Desember 2007; Vol. 5 No. 3: hal . 12-29.

Moleong, J., Lexy. 2010. Metodologi Penelitian Kualitatif. Edisi Revisi. Bandung: Cetakan ke-28. Remaja Rosdakarya.

Pals, L., Daniel. 2001. Seven Theories of Religion: dari Animisme E.B Taylor, Materialisme Karl Marx, Hingga 
Antropologi Budaya C. Geertz. Yogyakarta: Penerbit Qalam.

Rohani A, Zamree I, Lee HL, I M. 2005.Detection of Transovarian Dengue for Field Caught Aedes aegypti and Aedes albopictus Mosquitoes Using C6/36 Cool Line Culture and RT-PCR. Institue for Medical Research press. Kuala Lumpur;

Sowandoyo E, editor. Demam Berdarah Dengue pada Orang Dewasa, Gejala Klinik dan Penatalaksanaannya. Seminar Demam Berdarah Dengue di Indonesia 1998; RS Sumberwaras. Jakarta.

WHO. Pencegahan dan Penanggulangan Penyakit Demam Dengue dan Demam Berdarah Dengue. Jakarta: WHO \& Departemen Kesehatan RI; 2003.

WHO. Dengue: Guidlines for Diagnosis, Treatment, Prevention and Control. New

Edition. Geneva: World Health Organization; 2009.

Wirahjanto A, Soegijanto S. 2006. Epidemilogi Demam Berdarah Dengue, dalam Demam Berdarah Dengue Edisi 2. Surabaya: Airlangga University Press. 